\title{
Extended ageing time and temperature effects on quality of sub-primal cuts of boxed beef
}

\author{
Manuel Juárez, Ivy L. Larsen, Lorna L. Gibson, Wayne M. Robertson, \\ Michael E. R. Dugan, Noelia Aldai, and Jennifer L. Aalhus ${ }^{1}$
}

Agriculture and Agri-Food Canada, Lacombe Research Centre, 6000 C \& E Trail, Lacombe, Alberta, Canada

T4L 1W1. Contribution Number: 1146. Received 8 September 2009, accepted 19 April 2010.

\begin{abstract}
Juárez, M., Larsen, I. L., Gibson, L. L., Robertson, W. M., Dugan, M. E. R., Aldai, N. and Aalhus, J. L. 2010. Extended ageing time and temperature effects on quality of sub-primal cuts of boxed beef. Can. J. Anim. Sci. 90: 361-370. Most of the information indicating ageing improves tenderness has been collected on the loin and rib-eye muscles over relatively short ageing times, assuming that all muscles will react similarly. In the present study, the effect of extended ageing times on instrumental texture $(56 \mathrm{~d})$ and sensory characteristics $(42 \mathrm{~d})$ of six different beef sub-primals [striploin (SL), inside round (IR), outside round (OR), eye of round (ER), blade eye (BE) and chuck tender (CT)] was studied. The effects of two ageing temperatures $\left(1\right.$ and $\left.5^{\circ} \mathrm{C}\right)$ were also compared. In general, ageing increased tenderness $(P<0.05)$ of SL, BE, ER and CT sub-primals, although BE shear force increased after $42 \mathrm{~d}$ of ageing. On the other hand, ageing had no effect on IR tenderness $(P>0.05)$ and resulted in a decrease in tenderness of OR $(P<0.05)$ until day 35, with a later increase after $42 \mathrm{~d}$ of ageing. Increasing ageing temperature $\left(5^{\circ} \mathrm{C}\right)$ had limited effect on tenderness, but ageing time and temperature increases led to lower flavour and higher off-flavour intensity $(P<0.05)$ of the studied sub-primals. These results suggest that cutspecific maximum ageing times and rigid adherence to temperature maximums would be of benefit to optimize postslaughter processes and meat quality.
\end{abstract}

Key words: Beef, ageing, tenderness, muscle

Juárez, M., Larsen, I. L., Gibson, L. L., Robertson, W. M., Dugan, M. E. R., Aldai, N. et Aalhus, J. L. 2010. Incidence de la durée et de la température du rassissement sur la qualité des morceaux de bœuf en carton de coupe sous-primaire. Can. J. Anim. Sci. 90: 361-370. La plupart des données indiquant que le rassissement améliore la tendreté ont été recueillies sur les muscles de la longe et du faux-filet sur un temps relativement court, partant de l'hypothèse que les muscles réagissent tous de la même manière. Cette étude examine l'incidence d'un rassissement prolongé sur la texture (56 jours) et sur les propriétés organoleptiques (42 jours) de six coupes sous-primaires de bœuf [contre-filet (CF), intérieur de ronde (IR), extérieur de ronde (ER), noix de ronde (NR), noix de palette (NP) et bas de tendre (BT)]. Les auteurs ont aussi comparé l'effet de deux températures de rassissement $\left(1\right.$ et $\left.5^{\circ} \mathrm{C}\right)$. Dans l'ensemble, le rassissement accroît la tendreté $(P<0,05)$ des morceaux CF, NP, NR et BT, bien que la résistance de la NP au cisaillement augmente après 42 jours. Parallèlement, le rassissement n'a aucune incidence sur la tendreté de l'IR $(P>0,05)$ et diminue celle de l'ER $(P<0,05)$ jusqu'au $35^{\mathrm{e}}$ jour, avant de l'améliorer passé le $42^{\mathrm{e}}$ jour. Augmenter la température du rassissement $\left(5^{\circ} \mathrm{C}\right)$ a des effets restreints sur la tendreté, mais ajoutée à un rassissement plus long, la hausse de température atténue la saveur et intensifie l'arrière-goût $(P<0,05)$ des pièces de viande examinées. Ces résultats laissent croire que l'établissement d'une durée de rassissement adaptée au morceau et un strict respect de la température maximale optimiseraient les opérations suivant l'abattage et la qualité de la viande.

Mots clés: Bœuf, rassissement, tendreté, muscle

Tenderness is one of the most important quality attributes in beef (Jayasooriya et al. 2007). In fact, inconsistency in beef tenderness at the consumer level has been identified as one of the major problems facing the beef industry (Koohmaraie 1994). Ageing of beef is universally thought to improve tenderness (Johnston et al. 2001) as a result of the proteolysis of myofibrillar proteins, which is mediated in part by calpains (Koohmaraie 1996). Surprisingly though, much

${ }^{1}$ To whom correspondence should be addressed (e-mail: Jennifer.Aalhus@agr.gc.ca). of the data indicating ageing is advantageous has been collected on the loin and rib-eye muscles (Zamora et al. 1996; Monsón et al. 2005; Vieira et al. 2006; Braghieri et al. 2008; Destefanis et al. 2008). The assumption has been that all muscles will react similarly; however, not all sub-primal cuts respond as favourably as loin muscle to extended ageing (Aalhus et al. 2004; Janz et al. 2004; Gruber et al. 2006a). In fact, although previous US guides (Mies et al. 1999) recommended to industry an

Abbreviations: BE, blade eye; CT, chuck tender; ER, eye of round; IR, inside round; OR, outside round; SL, striploin 
universal ageing time of $12 \mathrm{~d}$, current recommendations (Gruber et al. 2006b) focus on the differences among beef sub-primals and individual muscles.

Recommended ageing times and what happens in industry are, however, two different things. Gill et al. (2002) reported boxed product on average exits packing plants, warehouses and retail store chillers after 4,14 or $22 \mathrm{~d}$ of ageing. However, maximum times for exiting packing plants, warehouses and retail store chillers were 24, 51 and $80 \mathrm{~d}$. Clearly, some product undergoes unnecessarily long ageing times with unknown effects on quality. As well, mean temperatures of ageing during distribution are $1-2^{\circ} \mathrm{C}$; however, maximum temperatures experienced during distribution were 10,6 and $5^{\circ} \mathrm{C}$ upon exiting packing plants, warehouses and retail store chillers, respectively. The effect of these extreme ageing times and temperatures on quality are unknown, but from both an economic (reduced refrigeration costs) and a food safety perspective, there would seem to be no need to hold meat longer than is beneficial from a quality perspective (Aalhus et al. 2004). Given the interactive effects of time, temperature and cut of beef on beef quality, the aim of the present experiment was to establish optimal conditions for beef ageing by examining the effects of extended ageing at two different temperatures for six different sub-primal cuts of boxed beef.

\section{MATERIALS AND METHODS}

\section{Assignment to Treatment}

Boxes of striploin (SL), blade eye (BE), inside round (IR), outside round (OR), eye of round (ER) and chuck tender (CT) were obtained from a commercial abattoir (Canada Grade AA) and shipped directly to the Lacombe Research Centre (LRC, AB, Canada) (Table 1). Samples were stagger-started with two subprimal cuts arriving on each of three subsequent days (RE and CT on Monday; IR and OR on Tuesday; SL and ER on Wednesday). Samples arrived 3, 5 and $6 \mathrm{~d}$ post-mortem to accommodate the commercial slaughter schedule and transportation to the LRC (SL and ER; $\mathrm{BE}$ and CT; IR and OR, respectively).

\section{Shear Force Determinations}

For shear force determinations, 24 pieces of each subprimal cut per cooler temperature were used (for a total

\begin{tabular}{|c|c|c|c|}
\hline & Acronym & Muscle & Wholesale cut \\
\hline Striploin & SL & Longissimus lumborum & Loin \\
\hline Blade-eye & $\mathrm{BE}$ & $\begin{array}{l}\text { Blade combination } \\
\text { (10 muscles) }\end{array}$ & Chuck \\
\hline Outside round & OR & Biceps femoris & Outside round \\
\hline Inside round & IR & Semimembranosus & Inside round \\
\hline Eye of round & ER & Semitendinosus & Outside round \\
\hline Chuck tender & $\mathrm{CT}$ & Supraspinatus & Chuck \\
\hline
\end{tabular}

of 48 pieces of each sub-primal cut). Upon arrival at the LRC sub-primals were cut into nine $2.5-\mathrm{cm}$ steaks, which were assigned to a specific cooking day corresponding to $0,7,14,21,28,35,42,49$ and $56 \mathrm{~d}$ of ageing. To avoid the intramuscular variation reported by several authors for texture attributes (Rhee et al. 2004; Shackelford et al. 1997), steak locations (1 to 9) were rotated to ensure equal representation of muscle location within each ageing time. Steaks were labelled, vacuum packaged, and placed on trays according to cooking day and cooler temperature $\left(1\right.$ and $\left.5^{\circ} \mathrm{C}\right)$. Trays were placed on racks within the assigned cooler.

Spear point temperature probes $(10 \mathrm{~cm})$ were inserted into the mid-point of all steaks assigned to $0 \mathrm{~d}$ (initial control). They were placed on a grill [Garland Grill ED30B (Condon Barr Food Equipment Ltd., Edmonton, $\mathrm{AB}$ )] preheated to approximately $210^{\circ} \mathrm{C}$. Steaks were grilled to an internal temperature of $40^{\circ} \mathrm{C}$, turned and cooked to a final temperature of $72^{\circ} \mathrm{C}$. Steaks were placed into polyethylene bags, sealed and immediately immersed in an ice/water bath to prevent further cooking. They were then transferred to a $1^{\circ} \mathrm{C}$ cooler to allow standing for a $24-\mathrm{h}$ period. Six cores, $1.9-\mathrm{cm}$ in diameter, were removed parallel to the fibre grain and peak shear force determined on each core perpendicular to the fibre grain [Instron 4301 Material Testing System equipped with a Warner-Bratzler cell and Series 9 Software (Instron Canada, Burlington ON)]. On each subsequent testing day, trays of steaks were removed from the cooler and shear force determined as described.

\section{Sensory Panel Determinations}

In addition to the samples utilized for shear values, 12 pieces of each sub-primal cut per cooler temperature were assessed for sensory characteristics. Again, boxes of SL, IR, OR, ER, BE and CT were obtained from a commercial abattoir and shipped directly to the Lacombe Research Centre, as described previously. Upon arrival at the research centre the SL, IR, OR and ER sub-primals were cut into twelve $2.5-\mathrm{cm}$ steaks. Steaks were assigned to a specific cooler temperature $\left(1\right.$ and $\left.5^{\circ} \mathrm{C}\right)$ and ageing time $(0,14,21,28,35$ and $42 \mathrm{~d})$ rotating steak location along the muscle to ensure each location was represented in each cooler temperature and cooking day. With the exception of $0 \mathrm{~d}$ of ageing samples, steaks were labelled, vacuum packaged, boxed according to cooking day and cooler temperature, and placed in the coolers. Day 0 samples were placed on trays in their respective coolers for overnight storage in preparation for cooking and serving the subsequent day. Due to the smaller size of the BE and CT sub-primals, 12 adequate size steaks could not be obtained, hence fewer ageing times were evaluated $(0,14,21$ and $28 \mathrm{~d})$. Again, steaks were assigned in a manner to ensure each location was represented in each cooler temperature $\left(1\right.$ and $5^{\circ} \mathrm{C}$ ) and cooking day. For the BE only, insufficient product was received to be able to evaluate 
both temperature treatments, hence this muscle was only evaluated at $1{ }^{\circ} \mathrm{C}$.

Steaks were prepared for panellists ensuring each muscle type and both storage temperatures were cooked and served together within a session. After the prescribed ageing time, steaks were removed from vacuum package and placed on a metal rack on a labelled tray. Steaks were cooked on an electric grill, using identical equipment and cooking techniques as described above for the shear values, and cooking time (seconds per gram) was calculated. Steaks were cut into $1.9-\mathrm{cm}^{3}$ pieces, avoiding large pieces of connective tissue and placed in a $70^{\circ} \mathrm{C}$ pre-warmed glass jar and covered with a glass lid. Panellists rated samples in booths under red lighting (124 1x). Panellist training was based on published standards and guidelines (American Meat Science Association 1995; American Society for Testing and Materials International 2005) with panellists previously extensively trained for evaluation of meat. Rating was done using nine-point descriptive scales for initial and overall tenderness $(9=$ extremely tender; $1=$ extremely tough), beef flavour intensity $(9=$ extremely intense beef flavour; $1=$ extremely bland beef flavour) and off flavour intensity $(1=$ extremely bland no off flavour; $9=$ extremely intense off flavour). Initial tenderness was rated on the first bite through the cut centre surface with the incisors, beef flavour and offflavour intensity between 10-20 chews, and overall tenderness after 25 chews. Results were recorded electronically.

\section{Statistical Analysis}

All data were analyzed separately for each muscle using the Mixed Model computer algorithm of the SAS Institute, Inc. (2003). For shear data, the final model included temperature, days of ageing and their interaction as main effects and muscle nested within temperature as the random effect. For sensory panel data, where the muscles were not large enough to assign all temperature by ageing times, within a muscle, the model was adjusted to remove the nesting of muscle within temperature. Means separation at the alpha 0.05 level were determined by paired T-test. Linear and quadratic contrasts up to $35 \mathrm{~d}$ and up to the end of the trial were conducted to further explore the effects of extended ageing on beef quality attributes of the different muscles.

\section{RESULTS}

No temperature effect (Table 2) or interaction between temperature and ageing time on shear force was observed for any muscle $(P>0.05)$. Reductions in shear force due to ageing became significant for SL $(P<0.0001)$, BE $(P<0.0001)$, ER $(P=0.0003)$ and CT $(P=0.0010)$, while a significant increase in OR $(P=0.0009)$ shear force was also observed (Table 3$)$. Reductions in shear force due to ageing in ER $(P=0.0003)$ and $\mathrm{CT}(P=0.0010)$ were not dramatic
Table 2. Effect of ageing temperature on shear force $(\mathrm{kg})$ for beef sub-primal cuts

\begin{tabular}{lrrcc}
\hline & \multicolumn{2}{c}{ Temp } & & \\
\cline { 2 - 3 } & \multicolumn{1}{c}{$1^{\circ} \mathrm{C}$} & $5^{\circ} \mathrm{C}$ & SEM & $P$ value \\
\hline $\mathrm{SL}^{\mathbf{z}}$ & 6.081 & 5.515 & 0.34 & 0.2522 \\
$\mathrm{BE}$ & 6.808 & 7.013 & 0.37 & 0.6967 \\
$\mathrm{OR}$ & 12.721 & 11.543 & 0.60 & 0.1814 \\
$\mathrm{IR}$ & 7.397 & 7.396 & 0.20 & 0.9957 \\
$\mathrm{ER}$ & 6.949 & 7.053 & 0.18 & 0.6858 \\
$\mathrm{CT}$ & 7.358 & 7.162 & 0.25 & 0.5846 \\
\hline
\end{tabular}

${ }^{\mathrm{z}} \mathrm{SL}$, striploin; BE, blade-eye; OR, outside round; IR, inside round: $\mathrm{ER}$, eye of round; $\mathrm{CT}$, chuck tender.

$(-1$ to $-2 \mathrm{~kg}$ ) taking $35 \mathrm{~d}$ to become significantly lower than $0 \mathrm{~d}$ shear forces. While the decrease in shear force was linear (Table 4$)$ for SL $(P<0.0001), \mathrm{BE}(P=0.0011)$ and ER $(P=0.0001)$, the pattern of shear force changes for the OR and CT was different, observing a linear increase $(P=0.0005)$ and decrease $(P=0.0032)$, respectively, in shear force up to $35 \mathrm{~d}$ only. Thus, the OR shear force increased, and after $21 \mathrm{~d}$ was $+4 \mathrm{~kg}$ greater than 0 $\mathrm{d}(P<0.05)$, but after $42 \mathrm{~d}$ some tenderization did occur and by $49-56 \mathrm{~d}$ shear forces were not different from $0 \mathrm{~d}$.

Sensory evaluations (Table 5) revealed no interactions between temperature and ageing time on initial and overall tenderness for any muscle $(P>0.05)$. Cooking time of ER was longer $(P=0.0099)$ at $5^{\circ} \mathrm{C}$. Initial tenderness scores of SL $(P=0.0053)$, OR $(P=0.0240)$ and IR $(P=0.0011)$, and overall tenderness of SL $(P=$ $0.0179)$ and IR $(P=0.0082)$ sub-primal cuts increased when meat was aged at $5^{\circ} \mathrm{C}$, compared with ageing at $1{ }^{\circ} \mathrm{C}$ (Table 5).

Cooking time of OR $(P=0.0391)$ and ER $(P=$ $0.0005)$ increased with increasing days of ageing, while the rest of the cuts were not affected $(P>0.05)$ (Table 6). Ageing also increased initial tenderness scores of SL $(P=0.0001)$ and $\operatorname{BE}(P=0.0016)$, and overall tenderness scores of SL $(P<0.0001), \mathrm{BE}(P=0.0016)$ and ER $(P=0.0173)$ sub-primal cuts, and decreased overall tenderness scores of OR $(P=0.0436)$ and IR $(P=0.0379)$, while no ageing effect $(P>0.05)$ was observed on initial tenderness scores from OR, IR, ER and CT, and overall tenderness scores from CT sub-primal cuts. However, not all those changes were linear over time. While the increase for OR cooking time increased linearly (Table 7) from day 0 to 35 only $(P=0.0288)$, for ER the increase was linear until $42 \mathrm{~d}$ of ageing $(P=0.0009)$. In the same way, initial tenderness scores of SL $(P=0.0002)$ and $\mathrm{BE}(P=0.0026)$ subprimal cuts increased linearly up to 35 and $28 \mathrm{~d}$, respectively. Overall tenderness scores of $\mathrm{BE}(P=$ $0.0002)$ sub-primal cuts increased linearly for $28 \mathrm{~d}$ of ageing. However, the strong quadratic component for SL $(P<0.0001)$ indicates a decrease at $42 \mathrm{~d}$ of ageing for overall tenderness scores from that cut. The effect of ageing on ER overall tenderness scores was not clear, 


\begin{tabular}{|c|c|c|c|c|c|c|c|c|c|c|c|}
\hline & \multicolumn{9}{|c|}{ Time } & \multirow[b]{2}{*}{ SEM } & \multirow[b]{2}{*}{$P$ value } \\
\hline & 0 & 7 & 14 & 21 & 28 & 35 & 42 & 49 & 56 & & \\
\hline $\mathrm{SL}^{\mathbf{z}}$ & $8.016 a$ & $6.203 b$ & $5.878 b c$ & $5.588 c d e$ & $5.138 e f$ & $4.871 f$ & $5.507 c d e$ & $5.662 c d$ & $5.319 \mathrm{def}$ & 0.29 & $<0.0001$ \\
\hline $\mathrm{BE}$ & $7.344 a b$ & $6.414 c d$ & $6.356 d$ & $6.425 c d$ & $6.665 b c d$ & $6.277 d$ & $7.232 b c$ & $7.353 a b$ & $8.126 a$ & 0.38 & $<0.0001$ \\
\hline OR & $10.450 c$ & $10.910 b c$ & $12.435 a b c$ & $14.486 a$ & $12.258 a b c$ & $14.130 a$ & $13.126 a b$ & $10.658 c$ & $10.735 c$ & 0.89 & 0.0009 \\
\hline IR & 7.975 & 7.287 & 7.046 & 6.965 & 6.874 & 7.198 & 7.833 & 7.536 & 7.852 & 0.41 & 0.4298 \\
\hline ER & $7.409 a b$ & $7.824 a$ & $7.684 a$ & $7.100 a b$ & $6.680 b c$ & $6.140 c$ & $7.370 a b$ & $6.146 c$ & $6.659 b c$ & 0.33 & 0.0003 \\
\hline CT & $7.826 a b$ & $6.963 \mathrm{bcd}$ & $7.399 a b c$ & $6.994 b c d$ & $7.341 a b c$ & $5.944 d$ & $8.064 a b$ & $8.107 a$ & $6.699 c d$ & 0.42 & 0.0010 \\
\hline
\end{tabular}

${ }^{\mathrm{z}} \mathrm{SL}$, striploin; BE, blade-eye; OR, outside round; IR, inside round: ER, eye of round; CT, chuck tender. $a-f$ Values in the same row with different letters are significantly different $(P<0.05)$.

since only a slight quadratic component $(P=0.0029)$ was observed up to $35 \mathrm{~d}$. On the other hand, ageing led to a linear decrease in OR $(P=0.0116)$ and IR $(P=0.0074)$ overall tenderness scores up to $35 \mathrm{~d}$, increasing again at $42 \mathrm{~d}$ of ageing.

No interaction between temperature and ageing time on flavour and off-flavour intensity scores was observed for any muscle $(P>0.05)$. Although no significant temperature effect $(P>0.05)$ was observed for flavour intensity scores of OR and ER, in general meat aged at $1{ }^{\circ} \mathrm{C}$ had higher $(P<0.05)$ flavour and lower $(P<0.05)$ off-flavour intensity ratings for most retail cuts (Table 5).

In general, flavour intensity scores decreased $(P<0.05)$ and off-flavour intensity scores increased $(P<0.001)$ with increasing days of ageing (Table 6$)$. These changes were all linear over time (Table 7; $P<0.0001$ ), except for BE flavour intensity scores which had a significant quadratic component $(P=0.0282)$, reaching its highest level after $14 \mathrm{~d}$.

\section{DISCUSSION}

Current theory suggests that meat stored at higher temperatures has a more rapid decline in shear values (Minks and Stringer 1972; Pierson and Fox 1976; $\mathrm{Wu}$ et al. 1981; Choi et al. 1995; Nowak and Korzeniowski 2004; Herrera-Méndez et al. 2005), although many of these studies used temperatures outside the range of normal storage temperatures (ranging from 20 to $30^{\circ} \mathrm{C}$ ). King et al. (2009) indicated that increasing the

\begin{tabular}{|c|c|c|c|c|}
\hline & $\begin{array}{l}\text { Linear all } \\
\text { times }\end{array}$ & $\begin{array}{c}\text { Quadratic all } \\
\text { times }\end{array}$ & $\begin{array}{l}\text { Linear } \\
\text { up to } 35 \mathrm{~d}\end{array}$ & $\begin{array}{l}\text { Quadratic } \\
\text { up to } 35 \mathrm{~d}\end{array}$ \\
\hline $\mathrm{SL}^{\mathrm{z}}$ & $<0.0001$ & $<0.0001$ & $<0.0001$ & $<0.0001$ \\
\hline $\mathrm{BE}$ & 0.0011 & $<0.0001$ & 0.0684 & 0.1491 \\
\hline OR & 0.8255 & $<0.0001$ & 0.0005 & 0.2948 \\
\hline IR & 0.5212 & 0.0238 & 0.1343 & 0.1377 \\
\hline ER & 0.0001 & 0.4560 & $<0.0001$ & 0.0457 \\
\hline CT & 0.7761 & 0.2463 & 0.0032 & 0.3565 \\
\hline
\end{tabular}

${ }^{\mathrm{z}} \mathrm{SL}$, striploin; BE, blade-eye; OR, outside round; IR, inside round: $\mathrm{ER}$, eye of round; CT, chuck tender. temperature from -0.5 to $3.3{ }^{\circ} \mathrm{C}$ had substantial effects on proteolysis, and subsequently shear force in longissimus lumborum and gluteus medius. However, the results obtained in the present study suggest that, when normal storage temperature ranges $\left(1-5^{\circ} \mathrm{C}\right)$ are used during meat ageing, the overall effect of temperature on tenderness follows the same trend, as previously reported by (Kim et al. 2007) for longissimus dorsi ( 0 and $4^{\circ} \mathrm{C}, 2,7,14,21,28$ and $49 \mathrm{~d}$ of ageing), but it is limited and muscle-dependant.

For a given ageing time, the inter-muscular variations in texture can be explained by their different fat and moisture content (Aalhus et al. 2004; Moreno et al. 2007), shape (Janz et al. 2006), sarcomere length (Willems and Purslow 1996), fibre type (Therkildsen et al. 2008; Lefaucheur 2009) and connective tissue (Light et al. 1985). However, the evolution of different texture parameters during ageing are more related to the rate of post-mortem rigor shortening (Olsson et al. 1994), myofibrillar proteolysis (Koohmaraie et al. 1996), moisture loss (Aalhus et al. 2004) and collagen breakdown (Purslow 2005), as well as to interaction among these factors.

In this context, SL shear force progressively decreased from day 0 to day 35. In all likelihood, rigor shortening was followed by myofibrillar breakdown, which is the classic response observed in longissimus muscle (Lawrie 1974). The increase in tenderness between days 0 and 35 was less dramatic for other sub-primal cuts (BE, ER and CT). This may have been due to differences in skeletal restrictions on the degree of rigor shortening, differences in proteolytic degradation of myofibrillar proteins and differences in muscle composition and structure. Shear force is generally accepted to decline over time postmortem, with the rate of decrease being more rapid initially and decreasing over time; however, almost all studies limit the time of ageing to a maximum of 30 d (Mies et al. 1999; Gruber et al. 2006a). There are also several reports in the literature, however, that indicate the pattern of tenderization for individual muscles (ex. the longissimus thoracis et lumborum) can be quite variable over $30 \mathrm{~d}$ post-mortem (Parrish et al. 1969; Stuby-Souva et al. 1994; Aalhus et al. 2004). In addition, in the present experiment, the IR was not 
$\overline{\text { Table 5. Effect of extended ageing temperature on sensory traits for beef }}$ sub-primal cuts

\begin{tabular}{|c|c|c|c|c|c|}
\hline & & \multicolumn{2}{|c|}{ Temp } & \multirow[b]{2}{*}{ SEM } & \multirow[b]{2}{*}{$P$ value } \\
\hline & & $1{ }^{\circ} \mathrm{C}$ & $5^{\circ} \mathrm{C}$ & & \\
\hline \multirow[t]{5}{*}{$\mathrm{SL}^{\mathrm{z}}$} & $\operatorname{CoT}^{y}$ & 5.51 & 5.55 & 0.33 & 0.8636 \\
\hline & IT & 6.00 & 6.45 & 0.20 & 0.0053 \\
\hline & OT & 6.03 & 6.38 & 0.18 & 0.0179 \\
\hline & FI & 5.02 & 4.71 & 0.12 & 0.0057 \\
\hline & OF & 2.45 & 3.05 & 0.12 & $<0.0001$ \\
\hline \multirow[t]{5}{*}{ OR } & CoT & 6.73 & 6.86 & 0.28 & 0.6062 \\
\hline & IT & 4.17 & 4.75 & 0.21 & 0.0240 \\
\hline & OT & 3.98 & 4.32 & 0.18 & 0.0895 \\
\hline & FI & 4.90 & 4.74 & 0.07 & 0.1035 \\
\hline & $\mathrm{OF}$ & 2.44 & 2.71 & 0.08 & 0.0105 \\
\hline \multirow[t]{5}{*}{ IR } & CoT & 5.70 & 5.74 & 0.22 & 0.8785 \\
\hline & IT & 4.93 & 5.67 & 0.18 & 0.0011 \\
\hline & OT & 5.06 & 5.54 & 0.13 & 0.0082 \\
\hline & FI & 4.96 & 4.58 & 0.10 & $<0.0001$ \\
\hline & $\mathrm{OF}$ & 2.64 & 3.19 & 0.10 & $<0.0001$ \\
\hline \multirow[t]{5}{*}{ ER } & CoT & 5.70 & 5.74 & 0.22 & 0.8785 \\
\hline & IT & 4.75 & 4.69 & 0.35 & 0.6699 \\
\hline & OT & 4.78 & 4.73 & 0.30 & 0.6891 \\
\hline & FI & 4.51 & 4.41 & 0.07 & 0.3340 \\
\hline & OF & 2.34 & 2.65 & 0.07 & 0.0007 \\
\hline \multirow[t]{5}{*}{$\mathrm{CT}$} & CoT & 8.31 & 8.25 & 0.38 & 0.8979 \\
\hline & IT & 5.13 & 5.15 & 0.32 & 0.9719 \\
\hline & OT & 5.38 & 5.41 & 0.26 & 0.9294 \\
\hline & FI & 4.70 & 4.35 & 0.07 & 0.0024 \\
\hline & OF & 3.07 & 3.50 & 0.12 & 0.0137 \\
\hline
\end{tabular}

${ }^{\mathrm{z}} \mathrm{SL}$, striploin; OR, outside round; IR, inside round: ER, eye of round; $\mathrm{CT}$, chuck tender.

${ }^{\mathbf{y}}$ CoT, cooking time; IT, initial tenderness; OT, overall tenderness; FI, flavour intensity; OF, off-flavour. Nine-point descriptive scales were used $(9=$ extremely tender, extremely intense beef flavour, extremely bland no off flavour; $1=$ extremely tough, extremely bland beef flavour, extremely intense off flavour). Blade-eye was only evaluated at $1{ }^{\circ} \mathrm{C}$.

affected by ageing, while the OR toughened considerably by $21 \mathrm{~d}$ and this was not resolved until 49-56 d. Some studies suggest that it is possible to select meats which have aged rapidly by $48 \mathrm{~h}$ post-mortem (Lepetit and Hamel 1998; Damez et al. 2008) and avoid long periods of storage and related costs. However, if ageing does not improve tenderness in certain muscles, unnecessary storage of these muscles could be avoided and the benefit could be even higher.

It is generally accepted that rigor sarcomere shortening is the cause of $24 \mathrm{~h}$ post-mortem toughening, and proteolysis is responsible for the decline in shear force during post-mortem storage (Wheeler and Koohmaraie 1994). Hence, tenderness improvement due to proteolysis is reduced in muscles that shorten less during rigor (Koohmaraie et al. 1996). In fact, some authors have concluded that the course of rigor mortis is more important for the ultimate tenderness than the course of ageing (Olsson et al. 1994). Traditional carcass Achilles tendon suspension leads to differences in muscle stretching depending on the anatomical position (Hostetler et al. 1972). In the present study, ageing had no effect on IR tenderness, and no improvement was observed for OR during the first weeks of ageing. Other authors (Eilers et al. 1996; Aalhus et al. 2004) have reported a lack of effect of ageing on IR tenderness, and this may be due to an initial limited rigor contraction resultant from a slower rate of temperature decline in the deep muscles of the hip (Aalhus et al. 2004).

The preponderance of ageing studies in the literature has led to the common belief that all ageing of meat results in improved tenderness, or as a worst case scenario, no change in tenderness. Part of the difficulty has arisen from the tendency to extrapolate data from one muscle (most commonly the longissimus thoracis et lumborum) to other muscles. As well, many studies do not go beyond a nominal ageing period (for example, 28 d). The study by Gill et al. (2002), although designed to examine the efficacy of the cold chain during distribution of meat for an assessment of microbial safety, also documented extended ageing can take place in industry. However, as long as all ageing was thought to be good ageing, ultimately resulting in improved tenderness, there would seem to be little harm in extending ageing time as a matter of convenience for distribution. The present data clearly demonstrate that going beyond optimum ageing times can result in deterioration in the tenderness in some sub-primal cuts.

Currently our understanding of why initial tenderization of meat is followed by toughening during the ageing period is incomplete. Early tenderization is likely to result from "resolution" or breakdown of the rigor linkages of the actomyosin proteins formed during the post-mortem period. Many researchers believe that breakdown of actomyosin bonds occur through enzymatic proteolysis (Dransfield 1993; Huff-Lonergan et al. 1996; Lawrence et al. 2004; Koohmaraie and Geesink 2006; Ouali et al. 2006; Kemp et al. 2010). On the other hand, there is some evidence to suggest intracellular osmotic changes over the ageing period can cause destabilization and denaturation of the myosin proteins resulting in rupture of the rigor linkages (Boehm et al. 1998), and that these changes are, at the same time, precursors to enzymatic proteolysis (Hattori and Takahashi 1988; Lawrence et al. 2004).

The question then arises as to why, following a period of tenderization, muscles begin to toughen again during extended ageing. One possibility may be related to increasing moisture losses over time, and the importance of intramuscular moisture levels during cooking, as observed for OR and ER muscles. A significant decrease in intramuscular moisture will lead to a lower heat transfer rate, with the subsequent increases in cooking time and losses to reach the same endpoint temperature. Moisture levels within the meat may play an important role in mediating the contribution of connective tissue to toughness. While total collagen content has been 


\begin{tabular}{|c|c|c|c|c|c|c|c|c|c|}
\hline & & \multicolumn{6}{|c|}{ Time } & \multirow[b]{2}{*}{ SEM } & \multirow[b]{2}{*}{$P$ value } \\
\hline & & 0 & 14 & 21 & 28 & 35 & 42 & & \\
\hline \multirow[t]{5}{*}{$\mathrm{SL}^{\mathrm{z}}$} & $\operatorname{CoT}^{y}$ & 5.21 & 5.67 & 5.41 & 5.37 & 5.80 & 5.73 & 0.41 & 0.6838 \\
\hline & IT & $5.27 b$ & $6.48 a$ & $6.35 a$ & $6.46 a$ & $6.33 a$ & $6.46 a$ & 0.25 & 0.0001 \\
\hline & OT & $5.23 c$ & $6.71 a$ & $6.54 a b$ & $6.30 a b$ & $6.23 a b$ & $6.15 b$ & 0.23 & $<0.0001$ \\
\hline & FI & $5.50 a$ & $5.43 a$ & $5.33 a$ & $4.82 b$ & $4.18 c$ & $3.94 c$ & 0.16 & $<0.0001$ \\
\hline & $\mathrm{OF}$ & $1.70 d$ & $2.13 c$ & $2.33 c$ & $2.99 b$ & $3.22 b$ & $4.14 a$ & 0.16 & $<0.0001$ \\
\hline \multirow[t]{5}{*}{$\mathrm{BE}$} & $\mathrm{CoT}$ & 6.66 & 7.63 & 6.93 & 6.17 & - & - & 0.51 & 0.2759 \\
\hline & IT & $4.76 b$ & $5.64 a$ & $5.62 a$ & $6.04 a$ & - & - & 0.24 & 0.0161 \\
\hline & OT & $4.74 b$ & $5.72 a$ & $5.82 a$ & $6.18 a$ & - & - & 0.21 & 0.0016 \\
\hline & FI & $4.94 a b$ & $5.46 b$ & $4.62 a$ & $4.24 a$ & - & - & 0.29 & 0.0296 \\
\hline & $\mathrm{OF}$ & $1.78 c$ & $2.68 b$ & $2.70 b$ & $3.58 a$ & - & - & 0.20 & 0.0003 \\
\hline \multirow[t]{5}{*}{ OR } & $\mathrm{CoT}$ & $6.13 c$ & $7.34 a b$ & $6.50 b c$ & $6.76 a b c$ & $7.44 a$ & $6.61 a b c$ & 0.38 & 0.0391 \\
\hline & IT & 4.56 & 4.83 & 4.42 & 3.94 & 4.05 & 4.97 & 0.32 & 0.1240 \\
\hline & OT & $4.39 a b$ & $4.27 a b c$ & $4.33 a b$ & $3.78 b c$ & $3.59 \mathrm{c}$ & $4.54 a$ & 0.26 & 0.0436 \\
\hline & FI & $5.56 a$ & $4.88 b$ & $5.00 b$ & $4.77 b$ & $4.77 b$ & $3.86 \mathrm{c}$ & 0.12 & $<0.0001$ \\
\hline & $\mathrm{OF}$ & $1.83 d$ & $2.21 \mathrm{c}$ & $2.40 \mathrm{c}$ & $2.47 \mathrm{c}$ & $2.90 b$ & $3.63 a$ & 0.13 & $<0.0001$ \\
\hline \multirow[t]{5}{*}{ IR } & $\mathrm{CoT}$ & 5.22 & 5.87 & 5.57 & 5.42 & 6.23 & 5.99 & 0.33 & 0.1782 \\
\hline & IT & 5.27 & 5.76 & 5.23 & 4.98 & 5.06 & 5.53 & 0.28 & 0.2972 \\
\hline & OT & $5.50 a b$ & $5.78 a$ & $5.19 a b c$ & $5.03 b c$ & $4.83 c$ & $5.47 a b$ & 0.22 & 0.0379 \\
\hline & FI & $5.64 a$ & $5.16 b$ & $5.26 b$ & $4.55 c$ & $4.54 c$ & $3.47 d$ & 0.13 & $<0.0001$ \\
\hline & $\mathrm{OF}$ & $2.80 b c$ & $2.30 \mathrm{de}$ & $2.18 e$ & $2.57 c d$ & $3.00 \mathrm{~b}$ & $4.66 a$ & 0.14 & $<0.0001$ \\
\hline \multirow[t]{5}{*}{ ER } & $\mathrm{CoT}$ & $5.56 b$ & $6.58 b$ & $6.35 b$ & $5.99 b$ & $6.15 b$ & $8.19 a$ & 0.39 & 0.0005 \\
\hline & IT & 4.55 & 5.06 & 4.73 & 4.88 & 4.60 & 4.52 & 0.37 & 0.1739 \\
\hline & $\mathrm{OT}$ & $4.34 c$ & $5.08 a$ & $4.73 a b c$ & $4.96 a$ & $4.48 b c$ & $4.94 a b$ & 0.33 & 0.0173 \\
\hline & FI & $4.99 a$ & $4.93 a$ & $4.80 a b$ & $4.55 b$ & $3.81 c$ & $3.68 c$ & 0.12 & $<0.0001$ \\
\hline & $\mathrm{OF}$ & $1.62 e$ & $2.06 d$ & $1.94 d$ & $2.61 c$ & $2.94 b$ & $3.80 a$ & 0.11 & $<0.0001$ \\
\hline \multirow[t]{5}{*}{ CT } & CoT & 8.53 & 8.72 & 7.15 & 8.72 & - & - & 0.53 & 0.1292 \\
\hline & IT & 5.14 & 5.22 & 5.13 & 5.07 & - & - & 0.40 & 0.9927 \\
\hline & $\mathrm{OT}$ & 5.48 & 5.47 & 5.40 & 5.25 & - & - & 0.35 & 0.9586 \\
\hline & FI & $5.32 a$ & $4.69 b$ & $4.33 c$ & $3.76 d$ & - & - & 0.11 & $<0.0001$ \\
\hline & $\mathrm{OF}$ & $2.36 c$ & $3.03 b$ & $3.46 b$ & $4.29 a$ & - & - & 0.16 & $<0.0001$ \\
\hline
\end{tabular}

${ }^{\mathbf{z}} \mathrm{SL}$, striploin; BE, blade-eye; OR, outside round; IR, inside round; ER, eye of round; CT, chuck tender.

${ }^{\mathbf{y}} \mathrm{CoT}$, cooking time; IT, initial tenderness; OT, overall tenderness; FI, flavour intensity; OF, off-flavour. Nine-point descriptive scales, were used $(9=$ extremely tender, extremely intense beef flavour, extremely bland no off-flavour; $1=$ extremely tough, extremely bland beef flavour, extremely intense off-flavour).

$a-e$ Values in the same row with different letters are significantly different $(P<0.05)$. Due to the smaller size, BE and CT were not evaluated at 35 and $42 \mathrm{~d}$.

related to tenderness differences among muscles, percent soluble collagen content has been related to tenderness changes associated with post-mortem ageing (Dutson 1974). Moreover, it is known that muscles with a high connective tissue content are generally tougher (Forrest et al. 1975) and moist heat cookery is often recommended during preparation to soften the connective tissue (Bejerholm and Aaslyng 2004). Meat with a high $\mathrm{pH}$ and high water-holding capacity (as dark firm dry meat) often is more tender when cooked (van der Wal et al. 1988), and the opposite occurs for meat that is exudative (pale soft exudative meat), which is tough when cooked (Aalhus et al. 1998). In addition, moistureenhanced meat has been shown to be more tender than non-enhanced meat when cooked to equivalent temperatures (Detienne and Wicker 1999; Prestat et al. 2002). Finally, culinary magazines extol the virtue of searing meat "locking in the moisture" to result in a more tender product, presumably by creating moist heat cookery conditions within the muscle. Since the waterholding capacity of the meat decreases over time due to the denaturation of the myofibrillar proteins (HuffLonergan and Lonergan 2005), it is possible the loss of moisture in aged muscles eventually reaches a point where connective tissue is insufficiently softened during cooking. Conversely, others have suggested that the loss of moisture causes collapse of the myofibrillar structure, changing the rate of heat transfer and hence the time of cooking (Davis et al. 1975). As well, the loss of sarcoplasmic enzymes such as the calpains as part of the drip, may also play a role in the changes in tenderness over time (Aalhus et al. 2004).

If both processes (breakdown of actomyosin linkages and moisture content contributing to softening of the connective tissue during cooking) are additive processes, this theory may even be used to explain the unique behaviour of the OR, which we observed to go through a period of toughening prior to tenderizing after extensive ageing. Compared with other muscles studied, the OR has a higher connective tissue content (McKeith et al. 1985). As well, this muscle is stretched to some degree in a hanging carcass, potentially resulting in 
JUÁREZ ET AL. - AGEING TIME EFFECTS ON BEEF QUALITY 367

\begin{tabular}{|c|c|c|c|c|c|}
\hline & & Linear All Times & Quadratic All Times & Linear Up to $35 \mathrm{~d}$ & Quadratic Up to $35 \mathrm{~d}$ \\
\hline \multirow[t]{5}{*}{$\mathrm{SL}^{\mathbf{z}}$} & $\operatorname{CoT}^{y}$ & 0.2212 & 0.9856 & 0.3191 & 0.9920 \\
\hline & IT & 0.0002 & 0.0023 & 0.0001 & 0.0020 \\
\hline & OT & 0.0049 & $<0.0001$ & 0.0002 & $<0.0001$ \\
\hline & FI & $<0.0001$ & 0.0001 & $<0.0001$ & $<0.0001$ \\
\hline & OF & $<0.0001$ & 0.0007 & $<0.0001$ & 0.1431 \\
\hline \multirow[t]{5}{*}{$\mathrm{BE}$} & CoT & $<0.0001$ & 0.0508 & - & - \\
\hline & IT & 0.0026 & 0.6155 & - & - \\
\hline & OT & 0.0002 & 0.4149 & - & - \\
\hline & FI & 0.0531 & 0.0282 & - & - \\
\hline & OF & $<0.0001$ & 0.4931 & - & - \\
\hline \multirow{5}{*}{ OR } & $\mathrm{CoT}$ & 0.1706 & 0.1174 & 0.0288 & 0.7890 \\
\hline & IT & 0.7457 & 0.1939 & 0.0775 & 0.3723 \\
\hline & OT & 0.3224 & 0.1506 & 0.0116 & 0.2345 \\
\hline & FI & $<0.0001$ & 0.1656 & $<0.0001$ & 0.0339 \\
\hline & OF & $<0.0001$ & 0.0020 & $<0.0001$ & 0.5049 \\
\hline \multirow[t]{5}{*}{ IR } & $\mathrm{CoT}$ & 0.0520 & 0.9877 & 0.0892 & 0.7999 \\
\hline & IT & 0.6959 & 0.7325 & 0.2358 & 0.2579 \\
\hline & OT & 0.0941 & 0.4100 & 0.0074 & 0.1617 \\
\hline & FI & $<0.0001$ & $<0.0001$ & $<0.0001$ & 0.4338 \\
\hline & $\mathrm{OF}$ & $<0.0001$ & $<0.0001$ & 0.3604 & $<0.0001$ \\
\hline \multirow[t]{5}{*}{ ER } & $\mathrm{CoT}$ & 0.0009 & 0.1214 & 0.4581 & 0.1582 \\
\hline & IT & 0.5172 & 0.0318 & 0.8421 & 0.0524 \\
\hline & OT & 0.1784 & 0.0940 & 0.4292 & 0.0029 \\
\hline & FI & $<0.0001$ & 0.0002 & $<0.0001$ & $<0.0001$ \\
\hline & $\mathrm{OF}$ & $<0.0001$ & $<0.0001$ & $<0.0001$ & 0.0157 \\
\hline \multirow[t]{5}{*}{$\mathrm{CT}$} & CoT & 0.6321 & 0.4241 & - & - \\
\hline & IT & 0.8815 & 0.8041 & - & - \\
\hline & OT & 0.6461 & 0.7676 & - & - \\
\hline & FI & $<0.0001$ & 0.1473 & - & - \\
\hline & OF & $<0.0001$ & 0.0688 & - & - \\
\hline
\end{tabular}

${ }^{\mathrm{z}} \mathrm{SL}$, striploin; BE, blade-eye; OR, outside round; IR, inside round: ER, eye of round; CT, chuck tender.

${ }^{\mathbf{y}} \mathrm{CoT}$, cooking time; IT, initial tenderness; OT, overall tenderness; FI, flavour intensity; OF, off-flavour. Due to the smaller size, BE and CT were not evaluated at 35 and $42 \mathrm{~d}$.

less extensive rigor linkages compared with other muscles. Koohmaraie (1996) showed that the impact of proteolysis on tenderness was minimal in the absence of rigor shortening. Hence moisture losses early postmortem could have a dominant effect in the OR, with the proteolytic changes to the actomyosin proteins having much less effect, resulting in decreased tenderness during the early phases of ageing. However, on its own, this theory does not adequately explain the increased tenderness that begins to occur in this muscle after extensive ageing ( $>35 \mathrm{~d})$, presumably when moisture losses are still continuing. Although generally not recognized as playing a significant role in postmortem tenderization because of late onset, enzymatic breakdown of connective tissue has been documented in the literature (Stanton and Light 1987, 1988, 1990a, b; Nishimura et al. 1995) and may be important in longaged muscles that have a large amount of connective tissue such as the OR. Thus, for muscles with high connective tissue content that do not undergo extensive rigor contraction, the toughening effect of moisture losses could play a significant role early on, followed by tenderization by enzymatic degradation of the connective tissue.
Ageing may also play a role in beef flavour development (Kato and Nishimura 1987). Although differences in fat or iron content among muscles have been reported to determine flavour differences (Calkins and Cuppett 2006; Yancey et al. 2006), in the present study, the effect of extended ageing on flavour was similar for all the muscles. Appropriate beef flavour decreased and offflavour intensity increased over time. Beef flavour results from the combination of basic tastes and odour derived from volatile compounds (Stetzer et al. 2008). According to previous studies, as meat ages, off-flavour attributes (such as bitter, bloody or liver-like aroma) increase, while desirable flavours (such as beefy or brothy) decrease (Spanier et al. 1997; Gorraiz et al. 2002). These changes are partly due to an increased availability of free amino acids and dipeptides (Hodge 1953; Mottram 1998; Mastrocola and Munari 2000; Dugan et al. 2004) and lipid oxidation products (Melton 1990), which react during cooking contributing to cooked beef flavours. Moreover, appropriate beef flavour intensity scores were higher when the muscles were aged at a lower temperature $\left(1^{\circ} \mathrm{C}\right)$ in the $\mathrm{SL}$, IR and CT, while all the muscles showed an increase in offflavour intensity (sour, lactate flavours) at higher storage temperature $\left(5^{\circ} \mathrm{C}\right)$, which may relate to bacterial 
growth. Free amino acids were measured for $21 \mathrm{~d}$ in the SL in the present study (Dugan et al. 2004), and generally increased over time but at 3 wk ageing at $5^{\circ} \mathrm{C}$ there was a reduction in glutamine, likely related to bacterial glutaminase activity (Gardner and Stewart 1966). Rancidity is brought about by the action of oxygen (oxidative rancidity) and is believed to be affected by, among other factors, lipolytic microorganisms (ketonic rancidity) (Pearson 1977). Moreover, increasing storage temperature has been shown to increase or accelerate these processes (Alford and Pierce 1961; Papon and Talon 1988).

In conclusion, the present study confirms that ageing of different muscles will not universally result in an improvement in tenderness. The mechanisms of tenderization during extended ageing are complex, and may be related to initial connective tissue content and moisture losses, in addition to the commonly accepted theory of rigor contraction followed by myofibrillar protein breakdown. In addition, a higher ageing temperature results in slight improvements in tenderness, but may have a negative impact on palatability of several muscles. No interactions were observed between the studied temperatures and times of ageing. Hence cutspecific ageing times should be developed for industry in order to optimize post-slaughter processes and meat quality. Of particular importance to industry is the development of ageing time maximums, such that meat quality does not deteriorate during extended distribution.

\section{ACKNOWLEDGEMENTS}

Dr. N. Aldai gratefully acknowledges the receipt of a research contract from the 7th European Community Program (Marie Curie International Outgoing Fellowship). And Dr. M. Juárez acknowledges the receipt of a NSERC fellowship funded through the AAFC ABIPFOBI program. Financial support for this work was provided by the Beef Cattle Research Council and the AAFC Matching Investment Initiative. Technical assistance provided by F. Costello and G. Croken, K. Landry, S. Landry and R. Thacker is gratefully acknowledged.

Aalhus, J. L., Best, D. R., Murray, A. C. and Jones, S. D. M. 1998. A comparison of the quality characteristics of pale, soft and exudative beef and pork. J. Muscle Foods 9: 267-280.

Aalhus, J. L., Dugan, M. E. R., Robertson, W. M., Best, D. R. and Larsen, I. L. 2004. A within-animal examination of postmortem ageing for up to $21 \mathrm{~d}$ on tenderness in the bovine longissimus thoracis and semimembranosus muscles. Can. J. Anim. Sci. 84: 301-304.

Alford, J. A. and Pierce, D. A. 1961. Lipolytic activity of microorganisms at low and intermediate temperatures. ii. Activity of microbial lipases at temperatures below $0^{\circ} \mathrm{C}$. J. Food Sci. 26: 518-524.

American Meat Science Association. 1995. Research guidelines for cookery, sensory evaluation and instrumental tenderness measurements of fresh meat. American Meat Science Association, Savoy, IL.

American Society for Testing and Materials International. 2005. American Society for Testing and Materials International. [Online] Available: http://www.astm.org/.

Bejerholm, C. and Aaslyng, M. D. 2004. Cooking of meat. Pages 343-349 in W. K. Jensen, C. Devine, and M. Dikeman, eds. Encyclopedia of meat sciences. Elsevier Academic Press, Amsterdam, the Netherlands.

Boehm, M. L., Kendall, T. L., Thompson, V. F. and Goll, D. E. 1998. Changes in the calpains and calpastatin during postmortem storage of bovine muscle. J. Anim. Sci. 76: 2415-2434.

Braghieri, A., Carlucci, A., Girolami, A. and Napolitano, F. 2008. Tenderness, $\mathrm{pH}$ and acceptability of meat from Podolian and Limousine $\times$ Podolian young bulls. J. Food Qual. 31: 490-502.

Calkins, C. R. and Cuppett, S. 2006. Volatiles compounds in beef and their contribution to off-flavors. National Cattlemen's Beef Association, Centennial, CO.

Choi, Y. I., Kim, Y. K. and Lee, C. L. 1995. Effects of packaging method and aging temperature on color, tenderness and storage characteristics of korean beef. Korean J. Anim. Sci. 37: 639-650.

Damez, J. L., Clerjon, S., Abouelkaram, S. and Lepetit, J. 2008. Beef meat electrical impedance spectroscopy and anisotropy sensing for non-invasive early assessment of meat ageing. J. Food Eng. 85: 116-122.

Davis, K. A., Huffman, D. L. and Cordray, J. C. 1975. Effect of mechanical tenderization, aging and pressing on beef quality. J. Food Sci. 40: 1222-1224.

Destefanis, G., Brugiapaglia, A., Barge, M. T. and Dal Molin, E. 2008. Relationship between beef consumer tenderness perception and Warner-Bratzler shear force. Meat Sci. 78: 153-156.

Detienne, N. A. and Wicker, L. 1999. Sodium chloride and tripolyphosphate effects on physical and quality characteristics of injected pork loins. J. Food Sci. 64: 1042-1047.

Dransfield, E. 1993. Modelling post-mortem tenderisation-IV: Role of calpains and calpastatin in conditioning. Meat Sci. 34: 217-234.

Dugan, M. E. R., Aalhus, J. L., Rolland, D. C. and Gibson, L. L. 2004. Effects of storage time and temperature on beef free amino acid levels. Canadian Meat Science Association, Ottawa, ON.

Dutson, T. R. 1974. Connective tissue. Pages 99-107 in Proceedings of the Meat Industry Research Conference, Washington, DC.

Eilers, J. D., Tatum, J. D., Morgan, J. B. and Smith, G. C. 1996. Modification of early-postmortem muscle $\mathrm{pH}$ and use of postmortem aging to improve beef tenderness. J. Anim. Sci. 74: 790-798.

Forrest, J. C., Aberle, E. D., Hedrik, H. B., Judge, M. D. and Merkel, R. A. 1975. Principles of meat science. W. H. Freeman and Co., San Francisco, CA.

Gardner, G. A. and Stewart, D. J. 1966. Changes in the free amino acid and other nitrogen compounds in stored beef muscle. J. Sci. Food Agric. 17: 491-496.

Gill, C. O., Jones, T., Rahn, K., Campbell, S., LeBlanc, D. I., Holley, R. A. and Stark, R. 2002. Temperatures and ages of boxed beef packed and distributed in Canada. Meat Sci. 60: $401-410$. 
Gorraiz, C., Beriain, M. J., Chasco, J. and Insausti, K. 2002. Effect of aging time on volatile compounds, odor, and flavor of cooked beef from Pirenaica and Friesian bulls and heifers. J. Food Sci. 67: 916-922.

Gruber, S. L., Tatum, J. D., Scanga, J. A., Chapman, P. L., Smith, G. C. and Belk, K. E. 2006a. Effects of postmortem aging and USDA quality grade on Warner-Bratzler shear force values of seventeen individual beef muscles. J. Anim. Sci. 84: 3387-3396.

Gruber, S. L., Belk, K. E., Tatum, J. D., Scanga, J. A. and Smith, G. C. 2006b. Industry guide for beef aging. National Cattlemen's Beef Association, Centennial, CO.

Hattori, A. and Takahashi, K. 1988. Localization of paratropomyosin in skeletal muscle myofibrils and its translocation during postmortem storage of muscles. J. Biochem. 103: 809-814.

Herrera-Méndez, C., Toledo-López, V., Abud-Archila, M., González-García, R., Ruiz-Cabrera, M. and Grajales-Lagunes, A. 2005. Reduction of ageing time of bovine meat by intermittent thermal treatments. Int. J. Food Prop. 8: 125-138. Hodge, J. E. 1953. Dehydrated foods, chemistry of browning reactions in model systems. J. Agric. Food Chem. 1: 928-943. Hostetler, R. L., Link, B. A., Landmann, W. A. and Fitzhugh, Jr., H. A. 1972. Effect of carcass suspension on sarcomere length and shear force of some major bovine muscles. J. Food Sci. 37: 132-135.

Huff-Lonergan, E. and Lonergan, S. M. 2005. Mechanisms of water-holding capacity of meat: The role of postmortem biochemical and structural changes. Meat Sci. 71: 194-204.

Huff-Lonergan, E., Mitsuhashi, T., Beekman, D. D., Parrish, Jr., F. C., Olson, D. G. and Robson, R. M. 1996. Proteolysis of specific muscle structural proteins by $\mu$-calpain at low $\mathrm{pH}$ and temperature is similar to degradation in postmortem bovine muscle. J. Anim. Sci. 74: 993-1008.

Janz, J. A. M., Aalhus, J. L. and Price, M. A. 2006. The effect of epimysial connective tissue on factors related to tenderness of beef semitendinosus. J. Muscle Foods 17: 43-55.

Janz, J. A. M., Aalhus, J. L., Robertson, W. M., Dugan, M. E. R., Larsen, I. L. and Landry, S. 2004. The effects of modified carcass chilling on beef carcass grade and quality of several muscles. Can. J. Anim Sci. 84: 377-384.

Jayasooriya, S. D., Torley, P. J., D'Arcy, B. R. and Bhandari, B. R. 2007. Effect of high power ultrasound and ageing on the physical properties of bovine semitendinosus and longissimus muscles. Meat Sci. 75: 628-639.

Johnston, D. J., Reverter, A., Robinson, D. L. and Ferguson, D. M. 2001. Sources of variation in mechanical shear force measures of tenderness in beef from tropically adapted genotypes, effects of data editing and their implications for genetic parameter estimation. Austr. J. Exp. Agric. 41: 991-996.

Kato, H. and Nishimura, T. 1987. Taste components and conditioning of beef, pork and chicken. Pages 289-306 in Y. Kawamura and M. R. Kare, eds. Umami: A basic taste. Marcel Dekker, New York, NY.

Kemp, C. M., Sensky, P. L., Bardsley, R. G., Buttery, P. J. and Parr, T. 2010. Tenderness - An enzymatic view. Meat Sci. 84: 248-256.

Kim, J. H., Cho, S. H., Seong, P. N., Hah, K. H., Kim, H. K., Park, B. Y., Lee, J. M., Kim, D. H. and Ahn, C. N. 2007. Effect of ageing temperature and time on the meat quality of longissimus muscle from Hanwoo steer. Korean J. Food Sci. Anim. Resour. 27: 171-178.
King, D. A., Wheeler, T. L., Shackelford, S. D., Pfeiffer, K. D., Nickelson, R. and Koohmaraie, M. 2009. Effect of blade tenderization, aging time, and aging temperature on tenderness of beef longissimus lumborum and gluteus medius. J. Anim. Sci. 87: 2952-2960.

Koohmaraie, M. 1994. Muscle proteinases and meat aging. Meat Sci. 36: 93-104.

Koohmaraie, M. 1996. Biochemical factors regulating the toughening and tenderization processes of meat. Meat Sci. 43: 5193-5201.

Koohmaraie, M., Doumit, M. E. and Wheeler, T. L. 1996. Meat toughening does not occur when rigor shortening is prevented. J. Anim. Sci. 74: 2935-2942.

Koohmaraie, M. and Geesink, G. H. 2006. Contribution of postmortem muscle biochemistry to the delivery of consistent meat quality with particular focus on the calpain system. Meat Sci. 74: 34-43.

Lawrence, T. E., Dikeman, M. E., Stephens, J. W., Obuz, E. and Davis, J. R. 2004. In situ investigation of the calciuminduced proteolytic and salting-in mechanisms causing tenderization in calcium-enhanced muscle. Meat Sci. 66: 69-75.

Lawrie, R. A. 1974. Meat science. 2nd ed. Pergamon Press, Oxford, UK.

Lefaucheur, L. 2010. A second look into fibre typing - relation to meat quality. Meat Sci. 84: 257-270.

Lepetit, J. and Hamel, C. 1998. Correlations between successive measurements of myofibrillar resistance of raw longissimus dorsi muscle during ageing. Meat Sci. 49: 249-254.

Light, N., Champion, A. E., Voyle, C. and Bailey, A. J. 1985. The role of epimysial, perimysial and endomysial collagen in determining texture in six bovine muscles. Meat Sci. 13: 137-149.

Mastrocola, D. and Munari, M. 2000. Progress of the Maillard reaction and antioxidant action of Maillard reaction products in preheated model systems during storage. J. Agric. Food Chem. 48: 3555-3559.

McKeith, F. K., Savell, J. W., Smith, G. C., Dutson, T. R. and Carpenter, Z. L. 1985. Physical, chemical, histological and palatability characteristics of muscles from three breed-types of cattle at different times-on-feed. Meat Sci. 15: 37-50.

Melton, S. L. 1990. Effects of feeds on flavor of red meat: A review. J. Anim. Sci. 68: 4421-4435.

Mies, D., Belk, K. E., Tatum, J. D. and Smith, G. C. 1999. Effects of postmortem aging on beef tenderness and aging guidelines to maximize tenderness of different beef subprimal cuts, Department of Animal Sciences, Colorado State University, Fort Collins, CO.

Minks, D. and Stringer, W. C. 1972. The influence of aging beef in vacuum. J. Food Sci. 37: 736-738.

Monsón, F., Sañudo, C. and Sierra, I. 2005. Influence of breed and ageing time on the sensory meat quality and consumer acceptability in intensively reared beef. Meat Sci. 71: 471-479.

Moreno, T., Pérez, N., Oliete, B., Carballo, J. A., Franco, D. and Monserrat, L. 2007. Effects on quality attributes of commercial veal pieces under different ageing treatments. Int. J. Food Sci. Technol. 42: 373-379.

Mottram, D. S. 1998. Flavour formation in meat and meat products: A review. Food Chem. 62: 415-424.

Nishimura, T., Hattori, A. and Takahashi, K. 1995. Structural weakening of intramuscular connective tissue during conditioning of beef. Meat Sci. 39: 127-133. 
Nowak, D. and Korzeniowski, W. 2004. Influence of modified conditions of ripening on meat tenderness and structural changes in skeletal muscle. Fleischwirtschaft 84: 100-103.

Olsson, U., Hertzman, C. and Tornberg, E. 1994. The influence of low temperature, type of muscle and electrical stimulation on the course of rigor mortis, ageing and tenderness of beef muscles. Meat Sci. 37: 115-131.

Ouali, A., Herrera-Mendez, C. H., Coulis, G., Becila, S., Boudjellal, A., Aubry, L. and Sentandreu, M. A. 2006. Revisiting the conversion of muscle into meat and the underlying mechanisms. Meat Sci. 74: 44-58.

Papon, M. and Talon, R. 1988. Factors affecting growth and lipase production by meat lactobacilli strains and Brochothrix thermosphacta. J. Appl. Microbiol. 64: 107-115.

Parrish, F. C., Jr., Rust, R. E., Popenhagen, G. R. and Miner, B. E. 1969. Effect of postmortem aging time and temperature on beef muscle attributes. J. Anim Sci. 29: 398-403.

Pearson, D. 1977. The chemical analysis of foods. 7 ed. Chemical Publishing Co., New York, NY.

Pierson, C. J. and Fox, J. D. 1976. Effect of postmortem aging time and temperature on $\mathrm{pH}$, tenderness, and soluble collagen fraction in bovine longissimus muscles. J. Anim. Sci. 43: 1206-1210.

Prestat, C., Jensen, J., McKeith, F. K. and Brewer, M. S. 2002. Cooking method and endpoint temperature effects on sensory and color characteristics of pumped pork loin chops. Meat Sci. 60: $395-400$.

Purslow, P. P. 2005. Intramuscular connective tissue and its role in meat quality. Meat Sci. 70: 435-447.

Rhee, M. S., Wheeler, T. L., Shackelford, S. D. and Koohmaraie, M. 2004. Variation in palatability and biochemical traits within and among eleven beef muscles. J. Anim Sci. 82: 534-550.

SAS Institute, Inc. 2003. SAS ${ }^{\circledR}$ user's guide: Statistics. SAS for windows. Version 9.1. SAS Institute, Inc., Cary, NC.

Shackelford, S. D., Wheeler, T. L. and Koohmaraie, M. 1997. Repeatability of tenderness measurements in beef round muscles. J. Anim Sci. 75: 2411-2416.

Spanier, A. M., Flores, M., McMillin, K. W. and Bidner, T. D. 1997. The effect of post-mortem aging on meat flavor quality in brangus beef. Correlation of treatments, sensory, instrumental and chemical descriptors. Food Chem. 59: 531-538.

Stanton, C. and Light, N. 1987. The effects of conditioning on meat collagen: Part 1. Evidence for gross in situ proteolysis. Meat Sci. 21: 249-265.

Stanton, C. and Light, N. 1988. The effects of conditioning on meat collagen: Part 2. Direct biochemical evidence for proteolytic damage in insoluble perimysial collagen after conditioning. Meat Sci. 23: 179-199.
Stanton, C. and Light, N. 1990a. The effects of conditioning on meat collagen: Part 3. Evidence for proteolytic damage to endomysial collagen after conditioning. Meat Sci. 27: 41-54. Stanton, C. and Light, N. 1990b. The effects of conditioning on meat collagen: Part 4. The use of pre-rigor lactic acid injection to accelerate conditioning in bovine meat. Meat Sci. 27: 141-159.

Stetzer, A. J., Cadwallader, K., Singh, T. K., McKeith, F. K. and Brewer, M. S. 2008. Effect of enhancement and ageing on flavor and volatile compounds in various beef muscles. Meat Sci. 79: 13-19.

Stuby-Souva, M. A., Lamkey, J. W. and Dolezal., H. G. 1994. Aging responses of beef muscles from different quality grades before and after freezing, Oklahoma Agric. Exp. Stn., Stillwater, OK.

Therkildsen, M., Houbak, M. B. and Byrne, D. V. 2008. Feeding strategy for improving tenderness has opposite effects in two different muscles. Meat Sci. 80: 1037-1045.

van der Wal, P. G., Bolink, A. H. and Merkus, G. S. M. 1988. Differences in quality characteristics of normal, PSE and DFD pork. Meat Sci. 24: 79-84.

Vieira, C., García-Cachán, M. D., Recio, M. D., Domínguez, M. and Sañudo, C. 2006. Effect of ageing time on beef quality of rustic type and rustic $\times$ Charolais crossbreed cattle slaughtered at the same finishing grade. Spanish J. Agric. Res. 4: 225-234.

Wheeler, T. L. and Koohmaraie, M. 1994. Prerigor and postrigor changes in tenderness of ovine longissimus muscle. J. Anim. Sci. 72: 1232-1238.

Willems, M. E. T. and Purslow, P. P. 1996. Effect of postrigor sarcomere length on mechanical and structural characteristics of raw and heat-denatured single porcine muscle fibres. J. Texture Stud. 27: 217-233.

Wu, J. J., Dutson, T. R. and Carpenter, Z. L. 1981. Effect of postmortem time and temperature on the release of lysosomal enzymes and their possible effect on bovine connective tissue components of muscle. J. Food Sci. 46: 1132-1135.

Yancey, E. J., Grobbel, J. P., Dikeman, M. E., Smith, J. S., Hachmeister, K. A., Chambers, IV, E. C., Gadgil, P., Milliken, G. A. and Dressler, E. A. 2006. Effects of total iron, myoglobin, hemoglobin, and lipid oxidation of uncooked muscles on livery flavor development and volatiles of cooked beef steaks. Meat Sci. 73: 680-686.

Zamora, F., Debiton, E., Lepetit, J., Lebert, A., Dransfield, E. and Ouali, A. 1996. Predicting variability of ageing and toughness in beef $m$. Longissimus lumborum et thoracis. Meat Sci. 43: 321-333. 